IRSTI 68.29.01

UDC 332.34

https://www.jpra-kazniiapk.kz

\title{
EFFECTIVE USE OF REMOTE AND NEAR-VILLAGE PASTURES OF THE REPUBLIC OF KAZAKHSTAN
}

\section{ҚАЗАҚСТАН РЕСПУБЛИКАСЫНЫН ШАЛҒАЙДАҒЫ ЖӘНЕ АУЫЛ МАНЫНДАҒЫ ЖАЙЫЛЫМДАРЫН ТИІМДІ ПАЙДАЛАНУ}

\section{ЭФФЕКТИВНОЕ ИСПОЛЬЗОВАНИЕ ОТДАЛЕННЫХ И ПРИАУЛЬНЫХ ПАСТБИЩ РЕСПУБЛИКИ КАЗАХСТАН}

\author{
A.A. TOREKHANOV*1 \\ Dr.Agr.Sc., Professor \\ A.I. SABIROVA \\ C.E.SC. \\ ${ }^{1}$ NPJSC «National Agrarian Science-Educational Center», Nur-Sultan, Kazakhstan \\ ${ }^{2}$ Kazakh Research Institute of Economy of Agro-Industrial Complex and Rural Development, \\ Almaty, Kazakhstan \\ *corresponding author e-mail: torehanov.aibyn@mail.ru
A.Ә. TӨPEXAHOB*
a.u.F.Ә., профресcop
А.И. САБИРОВА \\ Э.Ғ.К. \\ ${ }^{1}$ КеАҚ «Ұлттық аграрлық ғылыми-білім беру орталығы», Нұр-Сұлтан, Қазақстан \\ ${ }^{2}$ Қазақ аграрлық-өнеркәсіптік кешенінің экономикасы және ауылдық аумақтарды \\ дамыту ғылыми-зерттеу институты, Алматы, Қазақстан \\ *автордың электрондық поштасы: torehanov.aibyn@mail.ru

\section{A.A. TOPEXAHOB ${ }^{* 1}$ \\ Ә.C. -Х.H., профрессор \\ А.И. САБИРОВА \\ К.Э.H.} \\ ${ }^{1}$ НАО «Национальный аграрный научно-образовательный центр», \\ Нур-Султан, Казахстан \\ ${ }^{2}$ Казахский НИИ экономики агропромышленного комплекса и развития сельских \\ территорий, Алматы, Казахстан \\ *электронная почта автора: torehanov.aibyn@mail.ru
}

\begin{abstract}
The article is devoted to the discussion of issues related to the rational use of pasture lands, which form the basis of fodder base of animal husbandry. On the basis of statistical data on the presence of huge areas of pasture turnover and their feed capacity in the republic, the possibility of producing inexpensive ecologically clean livestock products on them is justified. Half of them (100 mln ha) are currently withdrawn from agricultural use and are classified as reserve lands. Their use in the near future- is a large reserve for improving food supply of the country's population with meat and meat products, and for increasing exports. The authors note that Kazakhstan has adopted a project to export 60 of thous. tons of beef. For production of such quantity of meat, it is necessary to keep livestock weighing 120 thous. tons, or about 300 thous. heads of cattle slaughtered annually for the sale of exported beef. It was revealed that $15 \%$ of the available pasture lands, or $26.5 \mathrm{mln}$ ha, are degraded, a significant part of them are located in the territory belonging to rural settlements. This is the reason for the deterioration of the environment in rural areas. The article provides data from many years of research by scientists on seasonal pastures "spring-summer-autumn" suitable for grazing of cattle, their area is $68 \mathrm{mln}$ ha, including in arid and desert regions - about $22.8 \mathrm{mln}$ ha.
\end{abstract}

Аңдатпа. Мақала мал шаруашылығы жемшөп базасының негізін құрайтын жайылымдық жерлерді ұтымды пайдалануға байланысты мәселелерді талқылауға арналған. Республикада жайылым айналымының орасан зор алаңдарының болуы және олардың жемшөп 


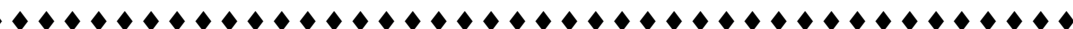
сыйымдылығы туралы статистикалық деректердің негізінде оларда арзан экологиялық таза мал шаруашылығы өнімдерін өндіру мүмкіндігі негізделген. Олардың жартысы (100 млн га) қазіргі уақытта ауыл шаруашылығы айналымынан шығарылып, босалқы жер санатына жатады. Оларды таяу болашақта пайдалану-ел халқын ет және ет өнімдерімен азық-түлікпен қамтамасыз етуді жақсартудың, экспорт көлемін ұлғайтудың үлкен резерві. Авторлар Қазақстанда 60 мың тонна сиыр етін экспорттау жобасы қабылданғанын атап өтті. Еттің осындай мөлшерін өндіру үшін тірі салмағы 120 мың тонна немесе шамамен жыл сайын экспортталатын сиыр етін өткізу үшін сойылатын 300 мың бас ірі қара малды ұстау қажет. Қолда бар жайылымдық жерлердің 15\% - ы немесе 26,5 млн га тозған жерлер анықталған, олардың едәуір бөлігі ауылдық елді мекендерге тиесілі аумақта орналасқан. Бұл ауылдық жерлердегі қоршаған орта жағдайының нашарлауының себебі болып табылады. Мақалада ірі қара мал жаюға жарамды "көктем-жаз-күз" маусымдық жайылымдары бойынша ғалымдардың көпжылдық зерттеулерінің мәліметтері келтірілген, олардың ауданы 68 млн га, оның ішінде құрғақ және шөлді аймақтарда - шамамен 22,8 млн га құрайды.

Аннотация. Статья посвящена обсуждению вопросов, связанных с рациональным использованием пастбищных угодий, составляющих основу кормовой базы животноводства. На основе статистических данных о наличии в республике огромных площадей пастбищеоборота и их кормоемкости обоснована возможность производства на них недорогой экологически чистой животноводческой продукции. Половина из них (100 млн га) в настоящее время выведены из сельскохозяйственного оборота и относятся к категории земель запаса. Их использование в ближайшей перспективе - большой резерв улучшения продовольственного обеспечения населения страны мясом и мясопродуктами, увеличения объемов экспорта. Авторы отмечают, что в Казахстане принят проект экспорта 60 тыс. тонн говядины. Для производства такого количества мяса необходимо содержать скот живой массой 120 тыс. тонн, или около 300 тыс. гол. крупного рогатого скота, ежегодно забиваемых для реализации экспортируемой говядины. Выявлено, что $15 \%$ имеющихся пастбищных угодий, или 26,5 млн га деградированы, значительная их часть находится на территории, принадлежащей сельским населенным пунктам. Это является причиной ухудшения состояния окружающей среды в сельской местности. В статье приводятся данные многолетних исследований ученых по сезонным пастбищам «весна-лето-осень», пригодным для выпаса КРС, их площадь составляет 68 млн га, в том числе в засушливых и пустынных регионах - около 22,8 млн га.

Key words: rangelands, degradation, desertification, water suply, fodder reserves, livestock population, livestock sectors, export of products, agricultural enterprises, farms.

Түйінді сөздер: жайылымдық алқаптар, тозу, шөлейттену, суландыру, жемшөп қоры, мал басы, мал шаруашылығы салалары, өнім экспорты, ауыл шаруашылығы кәсіпорындары, фермерлік шаруашылықтар.

Ключевые слова: пастбищные угодья, деградация, опустынивание, обводненность, кормозапас, поголовье скота, отрасли животноводства, экспорт продукции, сельскохозяйственные предприятия, фермерские хозяйства.

Introduction. Kazakhstan has huge resources of natural pastures and hayfields $179,2 \mathrm{mln}$ ha, today in agricultural use of agricultural entities only $73,4 \mathrm{mln}$ ha of pastures and about $20 \mathrm{mln}$ ha - at the disposal of citizens living in rural settlements.

According to scientists, the annual renewable feed stock on all hay and pasture lands is about $20 \mathrm{mln}$ tons of fodder units, which made it possible to keep $17 \mathrm{mln}$ conditional heads of cattle before the reform period (1990). During that period, all pasture and hay lands were in agricultural use. Currently, almost half of pasture land is in State ownership, belongs to the category of reserve lands and is not used by economic entities.
In recent years, more and more attention has been paid to the development of animal husbandry, and the increase in the number of animals has been observed. However, the level of provision of the population with meat and meat products has not reached the standard level and the planned export volumes are not being achieved. The solution of the issue can be achieved through the intensification of livestock industries and increase in the number of animal population, which requires an expansion of the areas of natural forage lands due to the development of reserve lands. Reserve lands are not only a source of cheap feed, but also as a basis for 
the formation of ecologically clean environment and food security of food products.

Specific feature of pasture lands in $\mathrm{Ka}$ zakhstan is their seasonality, which ensures the possible grazing of livestock with alternation according to the seasons of the year, as well as insufficient level of water availability. These circumstances do not allow the use of a significant part of the rangelands. This raises the problem of taking measures and effectively using the rangelands in Kazakhstan.

Materials and methods of research. A key issue in the use of remote pastures is water supply for animals. It is necessary to rehabilitate degraded pastures, especially around settlements, provide water supply to remote rangelands, restore old abandoned wells and build new ones where there is groundwater.

Particular attention is paid to the issue of involving reserve lands, which are mainly pastures, into economic circulation. This requires a special State program, its financial support, large investments in creation of water supply facilities using solar modules, wind turbines, construction of industrial and social facilities for livestock workers, road network and other infrastructure elements.

In the article methods of statistical analysis, monographic, computational and constructive are used.

Results and their discussion. Pasture management is a historically integral attribute of the economic and social development of Kazakhstan. There are over 13 million conventional heads in the country livestock. According to the forecasts of the KazRI of animal husbandry and fodder production, 30 million tons of fodder units can be obtained annually on natural pastures in the country. From an economic point of view, it is a source of reserves for the production of inexpensive, environmentally friendly products.

Is the development of this natural resource satisfactory? In total, out of 179,2 mln ha of pastures, $73,4 \mathrm{mln}$ ha belong to agricultural producers and about $20 \mathrm{mln}$ ha are pastures located in rural areas. Thus, $88 \mathrm{mln}$ ha of pastures are in economic use; according to official data, $15 \%$ of pastures are degraded. The remaining usable pasture area is $90 \mathrm{mln}$ ha of reserve land.

An important issue is the efficient use of natural pastures. In accordance with the goals set for agricultural sector, the desire to produce environmentally friendly products through the development of natural pastures is the precondition for export of meat $[1,2]$. Especially full development of remote pastures will make a great contribution to the growth of meat pro- duction. A separate topic is the process of feeding animals. For example, in Canada, where meat industry is developed, the bulk of meat production is beef, obtained as a result of grazing animals on pasture fodder. We need to take this experience into account.

In Kazakhstan, a project to export 60 thous.tons of beef, or in slaughter weight 120 thous.tons of live weight of livestock was presented. If a live weight of each head is 400 $\mathrm{kg}$, one can get 300 thous. heads of cattle. The question is, is it possible to keep these animals on forage of natural pastures? In the southeastern region, where beef is widespread in the country, the average grazing period is 180 days. Considering that each cow can eat $40 \mathrm{~kg}$ of green grass per day, 7.2 tons of hay -for the pasture period. Then one herd (150 heads) will require 1,080 tons of pasture grasses. If the average productivity of natural pastures in the region is 8 centners of green grass per hectare, then 300 thous. heads of cattle will need total $3.5 \mathrm{mln}$ tons of pasture fodder [3, 4].

According to the results of many years of research by scientists (A.A. Torekhanov, I.I. Alimaev and others), the need for seasonal pastures "spring-summer-autumn" suitable for grazing cattle in the country is more than 68 $\mathrm{mln}$ hectares. In Kazakhstan, only in arid and desert regions $22.8 \mathrm{mln}$ ha of pastures are suitable for keeping livestock [5].

The key issue for the efficient use of remote pastures is their water supply. Soil in eroded areas turns to dust and rises into the air. This is ecological stagnation. Such negative situations are known in world practice. In the beginning of the last century, $32 \mathrm{mln}$ hectares of land in the United States were eroded as a result of the neglected use of arid pastures. In this regard, in the 30 s of the last century, the US Congress adopted a special law. This law, known in history as "Taylor's Law", was aimed at regulating the grazing of livestock. Land use management was transferred to the Ministry of Internal Affairs and placed under strict State control; these pastures were put into operation only 40 years later.

In Kazakhstan, degraded pastures are often located close to rural areas, which leads to environmental degradation in the countryside. In this regard, the maximum use of remote pastures, elaborated and supported by the State, would help to resolve this issue. Of course, degradation of pastures is caused by their unsystematic use. Therefore, it is necessary to strictly control the pastures on which the livestock are located, and create all conditions for their restoration. When developing 
remote pastures, first of all, it is necessary to take into account the placement of migrants from rural areas. The current Land Code provides the necessary mechanisms for the implementation of such initiative [6].

The main thing is to define seasonal pastures for each animal species and organize effective grazing. However, to date, this issue has not been resolved by local administration. Electronic maps with characteristics of pastures, containing scientific advice and developments on the types of pastures, their capacity (for a conventional livestock), productivity and their use, typical for each region of Kazakhstan. Thus, all prerequisites for the use of pastures have been fulfilled, only organizational issues remain.

In case of insufficient capacity of natural pastures, it is necessary to involve reserve lands in agricultural circulation. For these purposes, funding is required within the frame of public support. Three-season crop rotations in one area are the main way to efficiently use the available reserves.

Taking into account that natural pastures in the country can continuously produce 30 $\mathrm{mln}$ tons of fodder per year, currently only $60 \%$ of this potential (17 mln tons) is used.

Livestock production on dairy farms and feedlots is provided with fodder from intensive plantations. Therefore, when expanding the area of pastures due to intensive technologies, the development of beef cattle breeding should be focused on maximum use of natural pastures. If scientific methods were fully implemented, intensive technologies and efficient use of pastures would increase, livestock population would increase, and their production would not be limited. Undoubtedly, the development of remote pastures will reduce production cost and allow to get environmentally friendly products. It should also be noted that if these factors lead to the increase in gross income, labor productivity per capita will increase.

The problem of rational use of natural forage lands within the land of settlements has become especially relevant today, since $70 \%$ of livestock moved in the process of privatization from public sector to households and is grazing near settlements. This leads to the development of pasture degradation processes, which causes enormous economic damage due to violation of ecological balance and leads to deterioration in the economic and social conditions of rural residents. In addition, the lack of organizational structures to regulate grazing of a huge livestock population, concentrated around the villages and located in the personal subsidiary farms of citizens, is observed.

The transfer of the share of livestock production to PSF and the lack of fixed pastures causes the need to additionally consolidate them at the expense of other categories of land and, first of all, reserve lands.

At present, degradation processes are localized in places of concentration of animals around the auls and open water reservoirs. The radius of severely degraded pastures around the auls up to $5 \mathrm{~km}$ or more is not subject to the regulation of livestock grazing, since the bulk of the rural population is not able to drive their livestock on their own to remote pastures. Therefore, the entire load in these conditions is on the land around the villages and auls. The reasons for this state of pastures are the constant unregulated grazing of livestock.

For the rational use of natural fodder lands and prevention of land degradation in the near-aul pastures, we suggest the following ways of organizing grazing of livestock that are in the personal subsidiary farms of the citizens:

* an extensive way of using pasture lands involves expanding the area and reducing the load of livestock on pastures through land lease, or additional use of reserve lands for distant pasture farming, which is provided free of charge, for a period of 5 years (Land Code of the RK);

${ }^{*}$ an intensive path - carrying out work on a fixed territory for superficial and radical improvement with sowing of grasses and organization of cultural irrigated pastures on the territory of lands of settlements;

* regulatory path - compliance with the feed capacity of the near-aul pastures assigned to the settlement with regulatory load and the number of livestock kept on them.

The first way can be considered if there are adjacent vacant lands of the special land fund, which can be used on a lease basis. Reduce the summer and winter load on the near-aul pastures at the expense of the distant lands of the reserve. In this case, a lease agreement must be drawn up, or a permit from the Akim for seasonal grazing must be issued, or a land plot should be obtained into private ownership from the category of reserve lands by means of buyout from the State at an auction.

The second way - involves the works on the observance of pasture rotation, a corral system of grazing livestock on irrigated pastures near the farm for cattle, carrying out a radical improvement through over-seeding of 
grasses. These measures will reduce the load on livestock on pastures and ensure more sustainable productivity.

The third way - is the most important, we recommend to graze livestock only according to the pastures capacities, taking into account the standard load for the seasons.

The main condition for the rational use of pastures is the normalized load of farm animals per unit area. At the same time, it is necessary to observe the seasonality of pastures and the terms of their use; take into account the capacity of pastures; feeding norms for animals grazed on pastures; permissible utilization rate of fodder mass; grazing density; calculation of the need for pasture fodder; daily rate of pasture fodder; insurance pasture fund; watering of pastures. Compliance with these conditions will ensure the preservation of pastures from degradation and desertification, their productive longevity and sustainable development of the livestock industry [7, 8].

Lists of owners of PSF and the number of their livestock by type and age groups supplied in these forms should be submitted to rural Akims for subsequent regulation of the processes of hiring seasonal labor force, or compliance with the priority of alternative family employment, replacement of workers using the shift method and assistance in organizing distant grazing of livestock in summer and winter pastures.

At the same time, taking into consideration that there is a certain difficulty in forming herds and combining the efforts and desire of many members of personal subsidiary farms to regulate the process of grazing of limited number of livestock on the territory of rural districts, we recommend when concluding agreements, approve the form of the agreement at general rural gathering with participation of the rural (village) Akim.

There is also big problems of pasture watering. It is necessary to improve the management of the use of groundwater, oasis irrigation, surface water sources (rivers, ponds, lakes, digging, etc.) through the use of environmentally friendly renewable energy sources: solar panels and wind turbines. This requires:

* Conducting studies of the state of groundwater basins in pasture areas, taking into account the physical and chemical composition; assessment of forecasted proven reserves by region based on their previously explored resources.

* Conducting approbation of modern desalination methods (reverse osmosis, hyperfiltration, nanofiltration) and research on the possibilities of using desalination of groundwater for drinking and watering of animals).

* Assessment of the possibility of organizing separate preparation of water for drinking needs and the use of source water for technical purposes and watering animals within the requirements of CNR.

* Development of a technology for local irrigation in areas of fodder production using groundwater with development of irrigation regimes for forage crops.

* Study of the operating mode of the used innovative technologies with the use of renewable energy sources [9].

* Zoning of the territories of the RK by solar radiation and wind regime.

Organizational measures for livestock grazing system include the organization of family farms and service cooperatives for the joint use of watering facilities, wind turbines, fodder production, marketing of products, provision and maintenance of basic means of production. Taking into account the weak interest of the young economically active population in unproductive work as shepherds, we suggest using the rotation mechanism of livestock workers on shift basis used in the raw materials industries, in particular in the mining industry.

An important role is given to the creation of social conditions in distant pastures. It is necessary to create living conditions for livestock workers similar to those in the settlement. The criterion can be a hamlet type of peasant farm, where a dwelling house with outbuildings, a hay storage, and temporary shelters during the period of stall keeping of animals will be built. Justification of the problems of employment and social development of distant areas, organizational form of operation and maintenance of facilities.

These measures will make it possible to effectively use the vast hay and pasture lands without disturbing the ecology of rural areas and creating favorable living conditions for the rural population [10].

\section{Conclusion}

1. Livestock production in Kazakhstan is a priority industry. Its development is based on natural pasture lands, the total area of which in the country together with hayfields $(4,9 \mathrm{mln} \mathrm{ha})$ is $184,1 \mathrm{mln}$ ha. Half of the pastures $(110 \mathrm{mln}$ ha) were converted to reserve lands in the early 90 s. The adoption of measures to improve the efficiency of pastures used by agricultural entities and the involvement of reserve lands in agricultural circulation in order to supply the population with food and increase export of products is today a strategic task of the country's agricultural sector. 
2. Analysis of the state of used pastures in the country revealed that $14 \%$ of them or $26.5 \mathrm{mln}$ ha are degraded. This is an environmental problem, especially for rural areas. Therefore, the transfer of livestock from degraded lands, primarily from near-village (near-aul) lands to empty reserve lands and creation of conditions there for the formation of family farms and collective cooperative farms, is becoming very important today for the management authorities of the industry.

3. In agricultural entities (agricultural enterprises and peasant farms) of livestock sector, the used pasture lands as main means of production must strictly observe the basic principles and rules of their rational use. This is, first of all, the seasonality of pastures, the terms of their use, accounting for the feed capacity of land, grazing density, the presence of insurance pasture fund. Compliance with these conditions will ensure the preservation of pastures from degradation, long-term use and sustainable effective development of animal husbandry.

4. The most important issue in the use of pastures in Kazakhstan is their watering. Most of the territory of land (pasture) resources is not watered. Therefore, it is necessary to improve management of groundwater use, oasis irrigation and surface sources (rivers, ponds, lakes). At the same time, renewable energy sources should be widely used: solar panels and wind turbines. The solution of these issues requires research on the application of innovative technologies for the use of renewable energy sources, zoning of the territory of the Republic of Kazakhstan in terms of solar radiation and wind regime.

5. Involvement of remote currently unused lands (pastures) requires the creation of social and living conditions on these lands for workers in livestock sector, close to the villages, that is, the construction of residential buildings with outbuildings, production facilities: a shelter for keeping livestock during the stall period, hay storage, insemination and veterinary service points. A road network must be developed connecting remote farms with large settlements where social conditions for agricultural workers are created.

\section{Список литературы}

1 Калиев, Г.А. Основные проблемы развития аграрного сектора Республики Казахстан / Г.А.Калиев, А.Б. Молдашев, Г.А. Никитина. - Алматы: Казахский НИИ АПК и развития сельских территорий, 2016.- 20с.

2 Молдашев, А.Б. Продовольственная безопасность Казахстана / А.Б. Молдашев,
М.Т. Кантуреев, А.Г. Мадиева // Проблемы агрорынка.- 2020.- N1.- C.11-18.

3 Тореханов А.А. Некоторые аспекты укрепления кормовой базы животноводства //Инновационные основы повышения интенсификации и эффективности развития животноводства и кормопроизводства: Матер. II Междунар. науч.-практ. конф. - Алматы, 2019. -C.325-330.

4 Бегембеков, К.Н. Мясная продуктивность и качество мяса бычков казахской белоголовой породы после нагула на естественных пастбищах и их соответствие международным стандартам / К.Н. Бегембеков, А.А. Тореханов // Техническое обеспечение сельского хозяйства.-2019.-№1. - С.153-159.

5 Тореханов, А.А. Природные и сеянные пастбища Казахстана / А.А. Тореханов, И.И. Алимаев. - Алматы: Нур-Прин, 2016.- 363с.

6 Стратегические меры по борьбе с опустыниванием в Республике Казахстан до 2025 года.- Астана, 2015. - 336 с.

7 Калиев, Г.А. Методика определения (максимальных) размеров земельных участков сельскохозяйственного назначения, которые могут находиться в аренде у физических и юридических лиц Республики Казахстан для ведения сельскохозяйственного производства / Г.А. Калиев, З.Д. Дюсенбеков, А.Б. Молдашев, А.И. Сабирова.- Алматы КазНИИ экономики АПК и РСТ,2017.- 60 с.

8 Национальна программа развития мясного животноводства на 2018-2027гг. [Электронный ресурс].-2018.- URL: http://www. zinref.ru/000_uchebniki/04600... (дата обращения: 22.10.2020).

9 Калиев, Г.А. Обоснование необходимости поэтапного обводнения пастбищ для развития в животноводстве / Г.А. Калиев, А.Б. Молдашев, А.И.Сабирова // В кн. «Развитие животноводства Казахстана на основе обводнения пастбищ с применением возобновляемых источников энергии».- Алматы, 2015. -C.18-23.

10 Молдашев, А.Б. Продовольственная безопасность Казахстана / А.Б. Молдашев //В кн. «Стратегия экономической безопасности и социальной стабильности общества Казахстана».- Алматы, 2019.- С.354.

\section{References}

1 Kaliev, G.A. The main issues of the development of agricultural sector of the Republic of Kazakhstan / G.A. Kaliev, A.B. Moldashev, G.A. Nikitina. - Almaty: Kazakh RI AIC and Rural Development, 2016.- 20 p.

2 Moldashev, A.B. Food security of Kazakhstan / A.B. Moldashev, M.T. Kantureev, A.G. Madieva// Problems of Agrimarket.-2020.-N1.-P.11-18.

3 Torekhanov A.A. Some aspects of strengthening the food base of livestock production // 
Innovative basis for increasing the intensification and effectiveness of the livestock production developmentandfodderproduction: Proc. II Int.scientific-practicalconf.- Almaty.-2019.-P.325-330.

4 Begembekov, K.N. Meat productivity and meat quality of Kazakh white-headed bulls after fattening on natural pastures and their compliance with international standards. Begembekov, A.A. Torekhanov // Technical support of agriculture. - 2019.- №1. - P.153-159.

5 Torekhanov, A.A. Natural and sowing pastures of Kazakhstan / A.A. Torekhanov, I.I. Alimaev. -Almaty: Nur-Prin, 2016.- 363 p.

6 Strategic measures to combat desertification in the Republic of Kazakhstan until 2025. Astana, 2015. - 336 p.

7 Kaliev, G.A. Methodology for determining (maximum) sizes of agricultural land plots that can be leased from individuals and legal entities of the Republic of Kazakhstan for agricultural production / G.A. Kaliev, Z.D. Dyusenbekov,
A.B. Moldashev, A.I. Sabirova. - Almaty KazRI AIC Economy and RD, 2017.- 60p.

8 National program on development of beef cattle breeding for 2018-2027 [Electronic resource].- 2018.- URL:http://www.zinref.ru/000_ uchebniki/04600 (date of access: 22.10.20).

9 Kaliev, G.A. Justification of the need for phased irrigation of pastures for development of livestock production / G.A. Kaliev, A.B. Moldashev, A. I. Sabirova // In the book. Development of cattle breeding in Kazakhstan based on irrigation of pastures with the use of renewable energy sources. -Almaty, 2015. -P.18-23.

10 Moldashev, A.B. Food security of Kazakhstan/A.B. Moldashev// In the book. Strategy of economic security and social stability of the society of Kazakhstan. - Almaty, 2019. - P. 354.

\section{Information about authors:}

Torekhanov Aibyn Adepkhanovish, Doctor of Agricultural Sciences, Professor, Academician of KazASKhN, Professor of Agronomy, Chairman of the Board of NPJSC "National Agrarian ScienceEducational Center", 010000, Kurgaldzhinskoe highway, 4A, Nur-Sultan, Kazakhstan, torehanov.aibyn@mail.ru, https://orcid.org/0000-0001-6502-0692

Sabirova Alla Ivanovna, Candidate of Economic Sciences, Associated Professor, Leading Researcher, Kazakh Research Institutel of Economy of Agro-Industrial Complex and Rural Development, 050057, Satpayev Street, 30-b, Almaty, Kazakhstan, sabirova_alla@mail.ru, https://orcid.org/0000-00023566-9519 